\title{
A EXPERIÊNCIA ARTÍSTICA E A VIVÊNCIA DE UM PROCESSO COLETIVO EM SALA DE AULA NO MESTRADO PROFISSIONAL EM ARTES DA UNIVERSIDADE FEDERAL DO PARÁ
}

\author{
Aníbal Pacha Correia \\ Bruce Cardoso de Macedo \\ Débora Cavalcante Cardoso \\ Hellen Katiuscia de Sá Conceição \\ Jaqueline Cristina Souza da Silva \\ José Ailton de Carvalho Arnauld \\ Lourdes Maria Carrera Guedes \\ Maridete Daibes da Silva \\ Priscila Romana Moraes de Melo
}

\section{Resumo}

Este ensaio apresenta um relato de experiência de um grupo de "artistas-professores-alunospesquisadores" da área de Artes Cênicas, formado durante a disciplina Experiência artística e a prática do ensino de artes na escola do curso de Mestrado Profissional em Arte na Universidade Federal do Pará, com o intuito de refletir sobre suas vivências em sala de aula, cuja metodologia abordada propiciou a construção de um processo coletivo, a partir de vários encontros, trocas e referências teóricas que, somados ao seu modo de fazer e vivenciar a arte, resultaram em um processo que levou à compreensão do binômio experiência artística e prática do ensino da arte, propiciando múltiplas reflexões sobre o ensino-aprendizagem da arte na escola.

\section{Palavras-chave:}

Experiência Artística; Ensino da Arte; Processo Coletivo.

\section{CONSIDERAÇÕES INICIAIS - PROCESSO COLETIVO: UMA ESCRITA BLOCADA}

Nesta escrita, encontram-se reflexões de um grupo, os chamados GESTUAIS, composto por nove "artistas-professores-alunos-pesquisadores" ligados às artes cênicas, formado durante a disciplina Experiência artística e a prática do ensino de artes na escola (abordagens metodológicas), do Programa de Mestrado Profissional em Artes (PROF-ARTES) da Universidade do Estado de
Resumen

This paper presents thoughts of a group of "artists-teachers-students-researchers" of the performing arts area, took from a collective reflexion in a discipline in the Professional Master course at the Federal University of Pará, in order to report their experiences in the classroom, in a unique methodology that led to the construction of the collective process, resulting a process that led to understanding of the binomial "artistic experience and practice of art education", from various meetings, exchanges and theoretical references which matched our contemplation to make and experience art, bringing multiple reflexions on the art of teaching and learning in school.

\section{Palabras Clave:}

Artistic Experience; Arte Education; Collective Process.

Santa Catarina (UDESC) na Universidade Federal do Pará (UFPA).

Essa disciplina, ministrada pelos professores doutores Lia Braga e Afonso Medeiros, teve como premissa metodológica a sala de aula como um espaço privilegiado de criação na relação entre a experiência artística e a prática do ensino da arte, o que possibilitou intensas práticas artísticas, gerando valiosos questionamentos, ponderações e construções de conhecimento. 
A partir de um caminhar coletivo, a escrita foi elaborada levando em consideração todos os sujeitos implicados neste processo, o qual foi estabelecido pelas negociações entre saberes e procedimentos provocados pelos professores a partir de diretrizes pautadas no diálogo entre o olhar e a vivência do ensino-aprendizagem em arte.

Assim, experiências, aprendizados, linguagens e ressignificações estão presentes neste gesto coletivo de escrever o que foi vivenciado.

\section{PRIMEIRO CAMINHO: DIÁLOGOS ENTRE LINGUAGENS ARTÍSTICAS}

A ressignificação de imagens, sons e gestos através da integração entre linguagens distintas não é tarefa fácil, nem de se planejar e muito menos de se executar. Ela se torna ainda mais complexa quando os agentes participantes são desafiados a expressarem-se através de linguagens que não estão em seus domínios.

A partir de estímulos comandados pelos professores desta disciplina, saímos de nossas "zonas de conforto" para adentrarmos no campo das experimentações - nos manifestando sem fazer uso da linguagem verbal -, já que precisávamos fornecer pistas para a percepção de uma questão que julgávamos ser relevante e de grande interesse a todos os envolvidos: possibilitar diálogos e interações entre áreas bem próximas; o que dificilmente acontece durante a formação de professores.

No primeiro momento, a fim de desenvolver uma atividade prática, a turma foi orientada a se separar em grupos por área de afinidades, conforme a atuação dos participantes. Surgiram, então, três grupos: os gestuais (artes cênicas); os sonoros (música); e os visuais (artes visuais).

Cada grupo, separadamente, precisava desenvolver a criação de uma cena, sem fazer uso da palavra, apropriando-se apenas dos elementos específicos de cada linguagem artística. Cada fragmento surgido desse primeiro passo seria apresentado posteriormente, lapidado e somado às demais linguagens. Desse modo, em salas separadas, os integrantes de cada grupo se reuniram para colocar em prática suas ideias. O elo entre os grupos eram os professores que acompanhavam as ações, interviam, teciam considerações e encaminhamentos necessários.

O procedimento do grupo dos gestuais iniciouse, primeiramente, com uma roda de conversas para socializar as ideias e suas experimentações. Esse primeiro momento serviu como norte para os passos posteriores.

O tema indutor do processo para a criação da cena foi "O FIM DO MUNDO". Elencamos as seguintes ideias sobre ele: dor, sofrimento, falta de água potável e ar puro. Essas palavras serviram como disparadores de provocações, aflorando sensações e reações nos integrantes do grupo. As experimentações alteravam, a todo instante, os pensamentos e os corpos. Assim, cada um escolheu o gesto que desenvolveria e, logo em seguida, o executou em uma cena que representasse gradativamente: o caminhar, o sentir sede, o cansaço, a falta de ar, a morte.

Durante as apresentações de cada grupo, fomos orientados pelos professores a anotar nossas impressões sobre os resultados, uns dos outros. Estes registros deveriam ser feitos individualmente, por cada participante de todos os grupos, produzindo, portanto, um relato pedagógico que possibilitasse a construção da memória de experiências e de aprendizagens.

A disciplina primava pela não utilização de conteúdos prontos para mostrar que a arte deve ser ensinada na prática, "um fazer junto", em que professores e alunos são parceiros atuantes em um meio onde suas ações afetam a todos, coletivamente. Compreendemos que para que isso ocorra, precisamos nos despir das "armaduras" que vestimos, precisamos olhar e agir uns com os outros com sentimento de criança, deixando a mente e o coração livres.

No documentário Tarja Branca - A Revolução que faltava (2014), dirigido por Cacau Rhoden, temos um grande exemplo. Nele, um dos entrevistados diz o seguinte: "Tarja branca é a medicina psicolúdica. Este é o remédio do futuro. No futuro o remédio não entrará pela boca, mas pela orelha. É a palavra que vai consertar as pessoas". Neste sentido, precisamos estar atentos e dispostos às novas experiências, libertar as crianças sufocadas em nós, despertar o corpo e a mente para novas possibilidades criativas e educativas, inclusive brincando, pois, brincando, verdades são ditas 
e ensinadas, mundos são explorados, corpos são criados, transformados a todo instante num processo de modelagem evolutiva.

Esse processo de ensino-aprendizagem permitiu uma amplitude de horizonte em todos os sujeitos envolvidos - professores regentes (Lia Braga e Afonso Medeiros) e nós, professores-alunos -, observado na individualidade, bem como na coletividade, nos auxiliando na retirada da trave que nos impedia de ver as possibilidades de junção, intervenção e apropriação de linguagens artísticas distintas.

Durante alguns encontros, corpos falaram, instrumentos dançaram e imagens cantaram em meio ao processo criativo, o qual, surgido do caos, se fez a gênese, e em meio à floresta urbana das relações materializadas, viveu e também morreu, para renascer em pura poética de relação simbólica entre o claro e o escuro.

\section{SEGUNDO CAMINHO: RELAÇÕES DE AUTOPOIESES}

O desdobramento deste exercício, orientado pelo professor Afonso Medeiros, consistia no seguinte: cada um de nós, dos gestuais, deveria sintetizar seu movimento inicial, construído para o exercíciobase comum do grupo, acoplando um sentido expressivo. Insidia em escolhermos uma imagem apresentada pelo grupo dos visuais, somando a um som apresentado no primeiro exercício pelos musicais. Feito isso, apresentamos essa intervenção, conscientes do acréscimo à nossa primeira célula criativa, com elementos oriundos das outras linguagens artísticas.

A partir desse recurso, tivemos consciência de que, embora cada linguagem criativa tenha sua própria expressividade, elas podem sofrer um estágio de releitura, passando pela ótica reflexiva do artistacriador que domina determinada linguagem ao invés de outras, e estas intervenções acabam sendo incorporadas, reafirmando e/ou auxiliando a construção poética do objeto artístico.

Conseguimos detectar neste estágio criativo do exercício proposto, uma relação de autopoiese, termo criado pelos biólogos chilenos Varela, Maturana e Uribe (1974), os quais destacam que as relações naturais e culturais são circulares, onde a estrutura, organização e determinismo estrutural do objeto em construção, sofrem mudanças em seus componentes, ressurgindo uma reordenação a cada resultado de diálogos dessas intervenções, porém mantendo as incursões das interferências externas ao mesmo objeto, como explica Mariotti:

\begin{abstract}
Mesmo sabendo que cada sistema vivo é determinado a partir de sua estrutura interna, é importante entender que quando um sistema está em acoplamento com outro, num dado momento dessa inter-relação a conduta de um é sempre fonte de respostas compensatórias por parte do outro. Trata-se, pois, de eventos transacionais e recorrentes. Sempre que um sistema influencia outro, este passa por uma mudança de estrutura, por uma deformação. Ao replicar, o influenciado dá ao primeiro uma interpretação de como percebeu essa deformação. Estabelece-se, portanto, um diálogo. Por outras palavras, forma-se um contexto consensual, no qual os organismos acoplados interagem. Esse interagir é um domínio linguístico (MARIOTTI, 1999, p.3).
\end{abstract}

Neste sentido, um objeto artístico não deixa de ser absorvido como um sistema vivo, um sistema construído a partir de um processo de criação que contém alma, corpo, energia e poética que se relaciona com seu entorno, gerando, por sua vez, novos diálogos a partir da experiência estética despertada no receptor.

Assim, se o indivíduo-criador atentar para seu próprio mecanismo de criação poética, ele perceberá que este acontece em estágios, tendo um primeiro impulso (em nosso caso, o comando inicial do exercício prático proposto pelo professor Afonso Medeiros), desdobrando em outros segmentos (como relações autopoiéticas acopladas no primeiro impulso).

O educador, quando lança mão de exercícios teórico-práticos que possibilitem a discussão em sala de aula sobre questões que normalmente não são compreendidas pelo pensamento dito linear, as regiões sensíveis e cognitivas de percepção estão sendo acionadas através da experiência estética. Posto que este tipo de percepção não se ensina, se sente, logo, falar sobre Arte é diferente de fazer Arte.

Quando o professor discorre sobre o tema, ele apenas está comentando sobre algo abstrato ao corpo do aluno, não possibilitando ao educando a chance de experimentar esteticamente a "Arte" por meio de seus canais perceptivos mais refinados. Ao passo que, quando o aluno experimenta (ou seja, 
realiza algum procedimento de criação artística), ele não só compreende as particularidades de determinada linguagem artística, como também desenvolve sua percepção cognitiva que circunda outros tipos de compreensão e inteligência.

\section{TERCEIRO CAMINHO: O TEXTO COMO ELEMENTO INDUTOR DE CRIAÇÃO COLETIVA}

Como parte dessa trajetória de experiências, deparamo-nos, em outro momento, com textos poéticos enquanto procedimentos metodológicos teórico-artísticos para atuação de práticas vivenciadas na referida disciplina. O poema "A função da arte/1", presente em 0 livro dos Abraços (2002) de Eduardo Galeano, e o trecho da música "Língua" (1984) de Caetano Veloso nos foram apresentados para serem encenados, visualizados e musicados a partir do trabalho coletivo dos grupos divididos pelas linguagens artísticas - gestos, imagens e sons.

E como traduzir tais textos sem usar a linguagem verbal, visto que esta é, em si, decodificada e comunica imediatamente seus signos? Eis o desafio: comunicar signos e significados somente através dos gestos, imagens e sons.

Sendo assim, neste dia, um de nós teve a oportunidade de abraçar o poema de Galeano, vivenciando toda a experiência artística poetizada nas palavras:

Diego não conhecia o mar. O pai, Santiago Kovakloff, levou-o para que descobrisse o mar. Viajaram para - Sul. Ele, o mar, estava do outro lado das dunas altas, esperando. Quando o menino e o pai enfim alcançaram aquelas alturas de areia, depois de muito caminhar, o mar estava na frente de seus olhos. E foi tanta a imensidão do mar, e tanto seu fulgor, que o menino ficou mudo de beleza. E quando finalmente conseguiu falar, tremendo, gaguejando, pediu ao pai: - Pai, me ensina a olhar!

(GALEANO, 2002, p. 12).

Tanto aquele que vivenciou o poema quanto nós que o contemplamos, sentimos a mudança, a emoção no momento da contemplação; vivenciamos, então, a experiência estética. 0 objeto artístico nos atingiu, causando no "eu espectador" a mudança sensível do olhar ou a ressignificação do que se vê, do que se contempla.

Este fenômeno de recriação artística, de ressignificação e de possibilidades de contemplação estética também ocorreu com a demonstração prática da linguagem sonora, quando representantes do grupo "sonoros" demonstraram musicalmente as nuances, arranjos e timbres diversos do trecho da música "Língua" de Caetano Veloso: "Se você tem uma ideia incrível é melhor fazer uma canção / Está provado que só é possível filosofar em alemão" (1984) e "...na arte ou na criação artística também necessitamos de experiências, de laboratórios. Descobertas de caminhos... uma vantagem que a arte tem em relação à ciência é a ressignificação." (MEDEIROS, 2015) ${ }^{1}$.

É com este espírito de reconstrução de saberes, re-olhar o mundo através dos objetos artísticos, que o texto de Galeano nos ofereceu a possibilidade de recriar noções relacionadas à educação, arte e cultura, pois, quando o pai se coloca à disposição do filho, dando as mãos e os olhos, vendo junto, aí se faz a mágica da descoberta de conhecimentos, um sentido de educação e ampliação dos horizontes de saberes.

No momento em que o menino confere sentido e significado ao mar, a partir da emoção do seu contato, ele nos traz a magia da arte, e quando amplia a sua percepção de ser e de estar no mundo, nos traz a potência do ensino através da arte.

Eu sou quando me vejo também no outro². Portanto, um dos princípios que norteiam as ações educativas em artes desenvolvidas em espaços formais ou não formais de ensino, deve ter como conduta um eixo de reflexão: a função comunicativa da arte que cria diálogos peculiares e reflete a memória, bem como os conhecimentos expressados pelas diferentes linguagens que a arte nos possibilita.

A contemplação estética que o texto nos proporcionou é importante quando pensamos também em aspectos da educação enquanto vivência: a própria vida e as pessoas conectadas com o mundo no momento presente, a relação da arte com o sagrado, trazem a dimensão do respeito, por ter a capacidade de conciliar os opostos, de aproximar os diferentes e de esvaziar o preconceito e a discriminação.

A arte como reveladora dos espaços encantados, evidenciados nos processos educativos, apontou caminhos às vivências e às práticas reveladoras desta disciplina, conciliando os potenciais das linguagens artísticas, possibilitando outros 
processos de ensino-aprendizagem para o ensino de artes nos espaços educativos onde atuamos.

Como indicação para o encontro seguinte, os professores propuseram um desdobramento deste exercício, procedendo desta forma:

1.Para o grupo dos sonoros: traduzir em sons o poema "A função da arte/1" (O livro dos Abraços de Eduardo Galeano);

2.Para o grupo dos gestuais: traduzir em gestos o trecho da música de Caetano Veloso;

3.Para o grupo dos visuais: traduzir em imagens tanto o poema quanto o trecho da música.

Este outro desafio educativo proposto neste universo didático-metodológico foi uma reviravolta de ações para se chegar não a um fim, mas à degustação da experimentação artística como prática de ensino em sala de aula.

A experiência e o ensino se fundem entre os educadores/alunos que somos neste processo; fazem-nos perceber quando nos encontramos em determinados papeis, seja de condutor seja de receptor das linguagens trabalhadas.

\section{QUARTO CAMINHO: PROCESSO DE ACUMULAÇÃO E TRADUZIBILIDADE DAS LINGUAGENS ARTÍSTICAS PARA O EXERCÍCIO PRÁTICO: O PROCESSO CRIATIVO.}

Chegamos em outra fase de andamento das atividades, momento em que o exercício artístico de aplicabilidade prática teve como objetivo a percepção das possibilidades e as impossibilidades de tradução das linguagens e os modos de operar entre elas.

$\mathrm{Na}$ busca de recuperar as referências dos procedimentos anteriores (primeira apresentação), não tivemos a intenção de mudar o sentido de nosso mote, "O FIM DO MUNDO", em sua segunda apresentação artística, mesmo com a participação de novos integrantes, os quais não estiveram presentes no primeiro momento. Continuávamos com a forma fragmentada, composta por elementos que, juntos, criaram a mesma unidade temática.

Cada grupo se apresentou, na presença dos outros, para serem observados em suas significações. Foram separadas, metodologicamente, as unidades/elementos de cada cena, dispostas da seguinte maneira: Gestuais com sete elementos, Sonoros com três e Visuais com dez.

O objetivo foi promover um diálogo como exercício de ideias, utilizando a análise interpretativa como feedback da percepção do outro sobre o que foi apresentado; perceber o que foi colocado em cena que não estivesse tão claro ou não estivesse tão presente na recepção. Esse procedimento serviu de condutor para que os elementos de cada grupo pudessem ser revistos, ajustados, reelaborados, expandidos ou simplesmente sintetizados.

Foram redigidas três listas a partir do que foi dito pelos grupos. Em seguida, o professor Afonso Medeiros, propôs um exercício: escolher um dos significados dos elementos de cada grupo para o outro grupo reproduzir com a sua linguagem. 0 objetivo era promover uma prática que permitisse observar o que acontece quando os elementos dos grupos são colocados juntos em cena, entretanto, com seus significados mantidos.

Observamos que, à medida que os exercícios foram sendo realizados, os significados foram se alterando, permitindo que uma relação entre eles fosse estabelecida, embora, talvez, algo tenha se perdido da ideia original. O que pensamos, escrevemos e colocamos no gesto, passou, nesse momento, por possíveis traduzibilidades de linguagens, revelando a importância de experienciar modos, metodologias de trabalhar no coletivo, como processos de criação no desdobramento entre o que faz, recebe e analisa esse fazer. Tal procedimento não somente proporciona a experiência com as linguagens artísticas e suas transmissibilidades, como também atua na formação de possíveis multiplicadores da audiência dessas artes.

Para a próxima experimentação, nos foi solicitado que, a partir da relação das palavras elencadas, destacássemos uma delas como eixo capaz de atravessar todas as outras em seus significados, servindo como elemento indutor para o processo de criação de novas cenas.

Assim, ficaram as escolhas dos eixos: Gestuais: Morte; Sonoros: Gênese; Visuais: Natureza e o urbano. 0 processo de construção foi compartilhado entre os professores e alunos, resultando em um conjunto de cenas, denominadas inicialmente de "performance pós-moderna", em que o público seria coautor e 
daria um direcionamento, uma interpretação.

O objetivo era ajudar-nos a perceber os caminhos de construção de significados do discurso poético e o que tinha de conotativo e denotativo nessas observações e análises do outro que lê as imagens decorrentes, neste caso, da criação artística de cada grupo.

Posteriormente, o professor enunciou outro exercício: cada grupo teria que apresentar uma cena utilizando como indutor o eixo das outras linguagens e, se possível, colocando elementos do seu eixo ou dos outros grupos. O primeiro grupo a ser trabalhado foi o dos sonoros - "gênese".

Nesta proposta, foi observada a disponibilidade corporal dos grupos. Os "visuais" utilizavam o corpo como suporte de suas experimentações, mas o mesmo não aconteceu com os "sonoros", pois o estado letárgico de seus corpos ficou evidente. Nos "gestuais", a equipe promoveu muitas discussões em detrimento do fazer, agir corporalmente, experimentar, sempre com muitas ideias, observando o tempo disponibilizado para esses exercícios.

Podemos supor que a separação dos grupos, em um primeiro momento, contribuiu para a não experimentação da criação coletiva articulando concepções e ideias entre as linguagens artísticas. No entanto, o processo de integração das linguagens se deu no momento de execução da célula criativa indutora de cada um: criado e concebido em separado. Pensamos que, talvez, ao promover a concepção das ideias juntos, poderse-ia quebrar essa lacuna, mas demandaria um tempo maior para tal prática.

Tivemos clareza que estávamos construindo um método em sala de aula próprio dessa turma, no qual levamos em consideração todos os sujeitos implicados no jogo estabelecido pelas negociações entre saberes e procedimentos, provocados pelos professores em um caminho versado entre prática e teoria, sobre diretrizes pautadas no que se propõem pelo olhar e o viver na experiência artística e no ensino de arte. Segundo Virgínia Kastrup (2010), "é impossível ensinar a arte, porque a arte não é informação. Deve-se criar condição para que a experiência com a arte aconteça. Não é um saber acumulativo, é algo que trabalha no sentido do cultivo de si".

\section{QUINTO CAMINHO: PROCESSO DE EXPERIMENTAÇÃO ARTÍSTICA E PEDAGÓGICA}

Dando continuidade a essas propostas, fomos encaminhados a um processo metodológico em que cada grupo, separadamente, iria propor cenas cujos elementos das três linguagens estariam envolvidos e, posteriormente, todos teriam que experimentar as propostas apresentadas.

Prosseguimos (gestuais) numa discussão acerca do significado da palavra morte, nosso eixo, e de como representá-la cenicamente. Nesse momento, houve a preocupação em integrar as linguagens. Pensamos em propor oficinas, partindo da linguagem gestual como condutora para construção da cena. Entre as propostas apresentadas, aproveitamos a ideia do pano, indicada pelos visuais.

Durante o processo de criação, pensamos em várias ações cênicas a serem experimentadas, entre elas: - Parangolé, por sua ação multissensorial e pelo seu significado etimológico "conversa fiada", o qual, por sua vez, foi relacionado com o vocalize dos "sonoros" (nãnãnãnã...) devido à associação desse som com o sentido de fofoca, falas, conversas; e o jogo com máscaras, como fio condutor do abstrato da morte e/ou vida, dando outro formato e sentido aos corpos em cena.

Aliado a essas ideias, pensamos e discutimos também sobre o significado de "orgasmo" como sendo uma "pequena morte" e assim começamos a alinhavar a primeira cena. A partir disso, sugerimos e experimentamos, corporalmente, exercícios para demonstração de como seria aplicado o jogo da máscara. Nesse contexto de criação artísticopedagógico coletivo, reafirmamos nosso perfil de "artista-professor-aluno-pesquisador", pois estávamos exercitando todos nossos papeis sociais ao mesmo tempo, numa indissociabilidade entre prática artística, prática pedagógica e pesquisa acadêmica.

Neste processo, investigamos, criamos, trocamos fazeres e saberes artístico-pedagógicos, os quais são indissociáveis por sua natureza, num processo de reciprocidade e engrandecimento durante todas as atividades descritas. Dewey (2009) propõe o conhecimento enquanto processo e não como produto dele. Nesse sentido, sua afirmação se relaciona com nossa caminhada na 


\section{GÊNE SE}

(Nascimento, origem, criação, célula, vida, luz)

\section{NATURE ZA \\ (Fluidez, resistência, ruptura)}

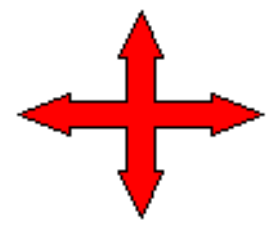

MORTE
URBANO

(Rigido, envelhecer, contraste)

(Fim, gozo, ciclo, cristalizado, luto)

Figura 1 - Eixos e suas significações.

Fonte: Acervo de Romana Melo

disciplina enquanto busca/pesquisa por reflexões, questionamentos e possíveis caminhos para nossas práticas artístico-pedagógicas, entretanto, sem pensar que chegamos a um conhecimento concludente, mas sim a um conhecimento necessário para continuarmos sempre nesse pensar e agir, em processo constante de estranhar para conhecer, sempre.

O exercício de ouvir o outro foi desafiador, pois tivemos que abrir mão de ideias, reavaliar nossos conceitos e práticas a partir dessa criação coletiva, onde cada um deixou sua impressão e, nesse sentido, as dificuldades, os limites e as potencialidades emergiram.

Vale ressaltar que algumas propostas foram abortadas na aula seguinte $\mathrm{e}$ isso teve um significado simbólico de vida e morte. Abortaramse as propostas iniciais para que pudessem surgir/ renascer outras, junto com os demais grupos. No entanto, ficou a matriz da proposta inicial, a qual foi levada até o fim na composição da cena final. A máscara representando a morte e o parangolé que acabou adquirindo um sentido muito próximo à experiência de Hélio Oiticica, com os corpos tomando formas diversas através do pano, com cores, luzes, texturas, danças, imagens projetadas, proporcionando, portanto, ação e sentido à gênese.

O "aborto" foi positivo, haja vista que dele ficou a experiência colaborativa de partilha, troca e aquisição de conhecimentos na elaboração das propostas iniciais das atividades/cenas e da própria concepção que foi configurando a disciplina - o fazer/atuar juntos, professores-alunos-artistas- pesquisadores - e por fim, o exercício do saber morrer para renascer outros saberes na criação.

\section{SEXTO CAMINHO: GÊNESE - O DESCOBRIMENTO DE NOSSOS GESTOS NOS PROCESSOS DE ENSINO E APRENDIZAGEM EM ARTES}

A partir disso, iniciou-se um processo de ressignificação das palavras (eixos) para a criação das cenas, as quais teriam que dialogar com todas as linguagens simultaneamente, propondo, com isso, um exercício poético/artístico que testasse os limites das linguagens trabalhadas. Conforme a figura 1 acima:

Cada grupo criaria, de forma colaborativa, um novo sentido a essas palavras. O exercício foi ressignificar esses sentidos dentro das linguagens gestual, sonora e visual. A opção de nosso grupo (gestuais) foi utilizar um grande tecido, fechado em círculo com a iluminação vinda de uma lâmpada incandescente (que depois foi substituída pela luz de uma lanterna). Criamos imagens corporais projetadas em sombras, surgindo uma linha tênue entre o real e o virtual, movimentando os corpos em sentido horário, bem lentamente, para que se criasse a leitura da forma, "é o corpo regido pela luz que se performatiza" (JALLAGEAS, 2002, p.280).

Isto gerou diversas interpretações, tais como o surgimento do cosmos, cuja matéria explode aleatoriamente e fica vagando, condensa e fica pulsante, que significa o núcleo da célula (ovo); a vida suprimida querendo sair para o mundo; o gozo; e no final a própria morte, ela que, simbolicamente, é o fim de um ciclo, para o início 
de outro, a própria gênese.

Se formos buscar o sentido etimológico da palavra gênese ${ }^{4}$, veremos que significa origem, princípio, criação. Para Marly Ribeiro Meira, a arte tem em seu princípio para a criação, capturar a vida onde ela está escondida e camuflada, nas coisas mais banais e cotidianas: "transformar é um desafio, de lidar com as mudanças das formas sem perda da estrutura viva que as sustenta" (MEIRA, 2007, p.122).

Há uma relação entre criador e aquilo que é criado, cuja pessoalidade do artista é impressa na obra, pois mesmo o indizível pode ser traduzido de forma poética através das linguagens da arte.

Essas construções aparecem a partir de reflexões do pensamento sensível, envolvendo de forma igualitária diferentes modos de percepção e concepção dos atos criadores de forma a estimular estados de invenção poética, de percepção estética e de pensar o mundo.

A luz, além de fenômeno concreto da natureza, indispensável à vida, também alimenta o imaginário, por meio de alegorias, metáforas e outras expressões das linguagens popular e erudita, utilizadas quer na comunicação comum, quer na criação artística e literária. Ela foi uma das maiores potências na criação coletiva desse trabalho; fez alusão ao nascimento que é a própria criação, um estado imanente de concepção da obra.

A mistura de diferentes elementos faz com que a obra seja híbrida, assim como é o mundo e a vida. Enquanto a obra não está potencializada para a materialidade, ela ainda é sombra, é gestação.

As formas de pensar o mundo causam abstrações nas coisas, começam a se modificar e aprendemos com elas, em um contínuo exercício de pensamento, de crítica, de ensinar e aprender, como uma espécie de "jogo sensorial", entre quem produz a obra e quem a contempla. Não basta apenas que a obra surja da cabeça do artista, é preciso que se estabeleça uma relação com quem a observa, o público que acrescenta sentidos a ela.

\section{SÉTIMO CAMINHO: O MAPA DA CRIAÇÃO}

Chegamos, então, ao momento em que grupos desenvolveram suas propostas artísticas, se apresentando de forma isolada e, logo em seguida, experimentaram a união dos três resultados.
A partir disso, traçamos o mapa desta criação. Foi definindo que os "visuais" iniciariam a cena com seu "cabo de guerra", enquanto os "sonoros" fariam a sonoplastia, localizados mais ao fundo da sala/palco. Os "gestuais", por sua vez, ficariam por trás dos "sonoros".

A personagem que representava o orgasmo como sendo a pequena morte, executada pela única bailarina do grupo, entraria durante a cena dos visuais. Em dado momento, os "gestuais" colocariam as máscaras e entrariam em cena já com o corpo alterado, enquanto os "sonoros" alterariam também a cadência da melodia musical. Ao final, "gestuais" e "visuais" cairiam ao chão, "mortos", e os "sonoros" colocariam seus instrumentos musicais entre os corpos, representando a morte completa.

Analisando o processo vivenciado, encontramos micro-processos bem interessantes para o contexto de sala de aula. Existiu ali um procedimento de criação em andamento e com linguagens distintas bem definidas, de forma que, o exercício de criar a cena sobre o tema "morte", se tornou um desafio para todos, em decorrência da impossibilidade de usarmos a linguagem verbal, o que nos tirou do eixo e nos colocou frente a uma prática que não estamos habituados.

Isso reforça que o processo de criação coletiva é um fator relevante. Nesse caso, experienciamos primeiro um coletivo separado em grupos, e depois o total coletivo. Essa forma de criar não é simples, envolve dificuldades que se revelam no percurso e devem ser solucionadas por meio de consenso ou pelo bom senso. Mas, acima de tudo, estas propostas dos professores agregam valores pedagógicos às atividades, trazendo os alunos para papeis que se alternam, ora como quem protagoniza a construção, ora como quem ouve e acata sugestões.

\section{OITAVO CAMINHO: ENSAIO GERAL - ÚLTIMOS AJUSTES}

Após essas definições, muito fora ajustado, em cada ensaio realizado durante este percurso, onde ideias e propostas novas surgiam a todo instante, e que não foram apenas detalhes, mas vislumbraram diversas possibilidades de representação.

E depois de tantos ensaios, chegamos à parte do processo intitulada como "Ensaio geral- últimos 
ajustes", que aconteceu no dia 15 de junho de 2015, no auditório do PPGArtes ${ }^{5}$. Este dia se iniciou com o círculo de energia, no intuito de concentrar nossas emoções para o trabalho seguinte. Posteriormente, definimos o prólogo: cada artista escolheu uma posição e um lugar, de maneira que todos ficassem distribuídos no espaço que compreendia a escada, funcionando como uma imagem no plano de fundo.

Logo em seguida, passamos as cenas sem interrupções e, ao mesmo tempo, fomos observando os acertos, para verificar o que não funcionou, ou, ainda, as possíveis modificações, guardando estas informações para discutirmos ao final. A partir dessas observações, começamos a organizar desde o início, a montagem da primeira cena.

Pensamos no desfazer da imagem do plano de fundo para outras ações: Gestuais - para pegarem o tecido, descerem a escada, se direcionarem ao centro do espaço e posicionarem o tecido no chão; Visuais - para entrarem no círculo formado com o tecido anteriormente, pelos gestuais; Sonoros para se posicionarem no espaço. Cada um definiu sua partitura corporal e demos prosseguimento à cena da gênese.

Durante a cena, observamos (gestuais e visuais) que precisaríamos estar atentos à mudança da melodia (sonoros) para que pudéssemos fazer com que a movimentação estivesse dialogando o mais correspondente possível: o momento de baixar o tecido para iniciar as pulsações, e o momento de abertura do mesmo. Após isso, definimos como levantaríamos o tecido e de que forma o retiraríamos da cena.

Na cena seguinte, "natureza e urbano", os sonoros, que na cena anterior ficavam circulando em torno do tecido emitindo os sons, se uniram aos visuais e alguns gestuais para fazerem o "muro", e a outra parte dos gestuais e visuais se deitaram no chão representando a "calçada". Outras duas participantes representaram a "planta trepadeira", que na metáfora do ato de sobrevivência ultrapassava o muro que impedia sua passagem através da resistência corporal.

Na "Morte", a penúltima cena, ao som do violoncelo, a dança acontecia suavemente, como se fosse o vento sendo fecundado, uma forma de preceder e conduzir para a cena posterior, onde os gestuais voltavam para a escada ao encontro das máscaras e ficavam estáticos como uma imagem, enquanto os visuais e sonoros interagiam.

No momento em que os gestuais colocavam as máscaras e se deslocavam para o centro, acontecia, de forma gradual, a mudança do estado de corpo, a transformação, traduzindo as características corporais que expressavam a identidade de cada máscara.

Em seguida, com o silenciar dos instrumentos, todos morriam, e com a morte acontecia a cena final, a oferenda dos instrumentos aos corpos que se encontravam espalhados pelo chão, trazendo a mesma intencionalidade do ato de se levar flores ao visitar pessoas queridas no cemitério.

Terminamos este ensaio geral com diálogos que nunca tiveram fim; propostas e mais propostas, dentre as mais ousadas: a inserção da projeção de imagens nos corpos durante algumas cenas, a qual seria experimentada no dia da apresentação do resultado de todo esse processo.

Em um espetáculo em que todos são protagonistas, lidar com processos criativos é uma tarefa árdua, uma vez que todos detêm conhecimentos acerca de sua arte e suas experiências artísticas afloram no momento da criação, fazendo com que a prática de ensino se encontre viva e presente de todas as formas.

Segundo Carlos Roberto Mödienger,

a docência em artes não pode ser isenta de um
diálogo constante entre o mundo das artes e o
mundo da educação. A ideia do professor-artista é
fazer arte na própria atuação com os alunos em sala
de aula o que supõe deixar-se surpreender com o
trabalho dos alunos, construir com eles, estimulá-
los e (não podá-los) a imaginar e arriscarem-se.
(MÖDIENGER et al., 2012, p.22)

E assim o fizemos. Experienciamos nossas práticas de ensino mutuamente e atuamos artisticamente em conjunto. Carmem Biasoli pressupõe dois tipos de práticas pedagógicas: a reiterativa e a reflexiva, devendo o professor de arte fazer a escolha da segunda, já que esta é a prática que condiz com os objetivos ideados com relação ao ensinoaprendizagem em arte:

Nessa prática, há a preocupação em criar e produzir uma mudança, em fazer surgir uma nova realidade material e humana qualitativamente diferente. Essa prática é reflexiva e criativa. Criativa porque 
transformadora da realidade, porque traduz a produção e a autocriação do próprio homem e a condição de lidar com o imprevisível e de criar novas soluções, novas situações. $E$ reflexiva porque, envolve uma ação crítica diante do saber e da realidade, construindo esse saber e intervindo nessa realidade. Na prática reflexiva, o ensino da arte enfatiza tanto o saber artístico como o fazer artístico, não havendo dicotomia entre teoria e prática. O aluno numa prática dessa natureza, é levado a usar sua experiência cognitiva não apenas para adquirir informações e destreza, habilidades manuais ou técnicas, mas para utilizar suas capacidades e habilidades cognitivas na apreensão da realidade para não imitá-la pura e simplesmente, e sim compreendê-la, recriá-la e apropriar-se dela para a construção de um conhecimento novo, de seu próprio conhecimento.(BIASOLI, 1999, p.116).

E se a disciplina se propôs a esta mesma reflexão, do artista-professor, muito tem da disciplina no resultado final alcançado. Fomos instigados a refletir sobre as nossas práticas, a criar e recriar, ressignificar, compreender e, por fim, construir nossos próprios conceitos acerca da arte que, simultaneamente, ensinamos e fazemos.

\section{CONCLUSÃO: SIMILARIDADES - O VERSADO E O EXPERIENCIADO}

A disciplina Experiência artística e a prática do ensino de artes na escola, ministrada pelos professores doutores Lia Braga e Afonso Medeiros, teve como premissa para sua metodologia a sala de aula como um espaço privilegiado de criação na relação entre a experiência artística e a prática do ensino da arte. Um caminho pedagógico escolhido na transmissão e apreensão do conhecimento com as artes e não através delas.

Podemos traçar similaridade da transmissão e a retenção do conhecimento com o estado do corpo em sala de aula entre a prática e sua análise crítica, como uma metodologia no trabalho com arte aplicado pelos professores. Neste sentido, podemos quebrar a ordenação escolar em uma de suas tramas para o surgimento de um espaço criativo. Não é um modo tão fácil de operar em sala de aula, pois demanda a não utilização de formas preconcebidas do ensino. Portanto, é de fundamental importância salientar a experiência artística como fonte de retenção e latência de conhecimento, a partir dos exercícios experienciados em sala de aula.

Nessa analogia e similaridades, ancoramos nosso entendimento próximo ao que foi dito pela professora Lia Braga em sua análise contextual sobre o título e a forma de como estão enunciados e ordenados os conteúdos dessa disciplina: "A prática do ensino da arte emerge da experiência artística" (VIEIRA, 2015) ${ }^{6}$, tecendo uma análise fundamentada da não existência binária entre experiência/prática, e que elas só se colocam nessa relação para uma abordagem metodológica.

Após percorrermos estes caminhos, perguntamonos: para que a arte na escola? A resposta é simples: para que o aluno adquira um pensamento universalizante, para que ele seja criativo, proponente, protagonista de suas ações, veja as coisas do mundo de diferentes pontos de vista, e seja capaz de construir seus próprios conceitos.

\section{NOTAS}

1. Fala do professor proferida durante a aula. Anotação feita em 18/05/15.

2. Pensamento baseado no poema "Eu não sou você, você não é eu", de Madalena Freire.

3. Conceito criado por Hélio Oiticica no fim da década de 1960.

4. Disponível em: <http://origemdapalavra.com. $\mathrm{br} / \mathrm{site} /$ palavras/genese/>. Acesso em: 23 out. 2015.

5. Localizado na Avenida Governador Magalhães Barata, n.) 611, CEP 60060-281, Belém-ParáBrasil. Homepage: www.ppgartes.ufpa.br/site.

6. Fala da professora proferida durante a aula. Anotação feita em 13/04/15.

\section{REFERÊNCIAS}

BIASOLI, Carmem Lúcia Abadie. A formação do professor de arte: do ensaio à encenação. (Coleção Magistério: Formação e trabalho pedagógico). Campinas: Papirus, 1999.

CERTEAU, Michel de. A invenção do cotidiano: artes de fazer. Petrópolis: Vozes, 1994.

CUNHA, Rosemeire Ribeiro. Transformação e ressignificação de objetos comuns incorporados à arte. 2011. 23f. Monografia 
(Licenciatura em Artes Visuais). Universidade de Brasília, Universidade Aberta do Brasil, XapuriAC, 2011. Disponível em: <http://bdm.unb.br/ handle/10483/4547>. Acesso em: 28 jun. 2015.

DELEUZE Gilles. o que é um dispositivo. In:____. O mistério de Ariana. Tradução e prefácio de Edmundo Cordeiro. Lisboa: Ed. Vega Passagens, 1996. Disponível em: <http://www. academia.edu/4026536/0_que_\%C3\%A9_um_ dispositivo>. Acesso em: 24 jun. 2015.

Foucault. São Paulo: Brasiliense,

2005.

DEWEY, John. A valoração nas ciências humanas. Organização e notas de Cunha, M. V; Cianflone, A. R. L; Andrade, E. N. F. Campinas: Autores Associados, 2009 (Coleção Clássicos da Educação).

FLORENTINO, A. A pesquisa qualitativa em artes cênicas: romper os fios, desarmar as tramas. In: TELLES, N. (Org.). Pesquisa em artes cênicas: textos e temas. Rio de Janeiro: E-papers, 2012.

FOUCAULT, Michel. Microfísica do poder. Rio de Janeiro: Ed. Graal, 1998.

FREIRE, Madalena. Eu não sou você, você não é eu. In: Educador. São Paulo: Paz e Terra, 2008. p. 95-96.

GALEANO, Eduardo. 0 livro dos abraços. Tradução de Eric Nepomuceno. 9( ed. Porto Alegre: L\&PM, 2002.

KASTRUP, Virgínia; PASSOS, Eduardo; ESCÓSSIA, Liliana da. Pistas do método da cartografia: pesquisa-intervenção e produção de subjetividade. Porto Alegre: Sulina, 2010.

JALLAGEAS, Neide. Corporalidades em Trânsito: Performances de Luz. In: GARCIA, Wilton; LYRA, Bernadette (org.). Corpo E Imagem. São Paulo: Arte \& Ciência, 2002.

MARIOTTI, Humberto, Autopoiese, Cultura e Sociedade. Disponível em: <http://www.dbm. ufpb.br/ marques/Artigos/Autopoiese.pdf >. Acesso em: 20 jun. 2015.

MATOS, Kleytson. Os parangoles de Oiticica. Publicado no blog oficial da Obvious. Disponível em: < http://lounge.obviousmag.org/haraquiri_
sertanejo/2012/08/Os-Parangoles-deOiticica-.html>. Acesso em: 21 maio 2015.

MEIRA, Marly Ribeiro. Filosofia da Criação: Reflexões sobre o Sentido do Sensível. Porto Alegre: Mediação, 2007.

MÖDINGER, Carlos Roberto; SANTOS, Cristina Bertoni dos; VALLE, Flávia Pilla do; LOPONTE, Luciana Gruppelli. Práticas pedagógicas em artes: espaço, tempo e corporeidade. Erechim: Edelbra, 2012.

OSTROWER, Fayga. Criatividade e processos de criação. 29 ed. Petrópolis: Vozes, 2013.

TELLES, Narciso. Pedagogia do teatro e o teatro de rua. Porto Alegre: Mediação, 2008.

FILME

RHODEN, Cacau. Tarja Branca - A Revolução que Faltava. Filme-documentário. Duração: 80min. Brasil: Maria Farinha Filmes, 2014.

\section{MÚSICA}

VELOSO, Caetano. Língua, 1984. 


\section{Sobre os autores}

\section{Aníbal Pacha Correia}

Diretor, ator, bonequeiro, figurinista e cenógrafo. Integra o Grupo In Bust - Teatro com Bonecos. Discente do Mestrado Profissional em Artes (PROFARTES). Bolsista CAPES/UAB 20142016. Possui graduação em Engenharia Civil pela Universidade Federal do Pará (1982). É docente da Universidade Federal do Pará, locado no Instituto de Ciências da Arte - Escola de Teatro e Dança - UFPA. Sua trajetória artistica se configura principalmente nos seguintes temas: teatro de animação (direção, ator-manipulador e bonequeiro); teatro (direção, cenografia, figurino e adereços); vídeo e cinema (direção,direção de imagem, direção de arte e figurino); televisão (programa infantil Catalendas, da Tv Cultura do Pará, com o In Bust Teatro com Bonecos, na função de direção artistica, bonequeiro, cenógrafo e intérprete) e artes plásticas (quatro exposições individuais e duas coletivas).

\section{Bruce Cardoso de Macedo}

Discente do Mestrado Profissional em Artes (PROFARTES). Concluinte da Especialização em EJA ARTES - AMAZÔNIA - UFPA. Coordenador do Projeto de Extensão Escritório Experimental da Cena/UFPA. Docente da Escola de Teatro e Dança da UFPA, graduado em Educação Artística pela Universidade Federal do Pará (2007). Colaborador do Projeto de Pesquisa TAMBOR: Estudos de Carnaval e Etnocenologia. Colaborador dos Projetos de Extensão: Auto do Círio, Cena Aberta, e GTU - Grupo de Teatro Universitário. Disciplinas que ministra: Elementos da Plástica, Cenotecnia, Cenografia, Experimentação Cenográfica, Máscara e corpo, Fundamentos dos Elementos Cênicos e Acessórios Especiais. Possui experiência na área das artes: máscaras, cerâmica, esculturas, adereços, alegorias, objetos cênicos, cenotecnia e cenografia.

\section{Débora Cavalcante Cardoso}

Artista-pesquisadora, bailarina, professora de dança e coreógrafa. Mestranda do Programa de Pós-graduação em Artes - ICA/UFPA.
Graduada em Licenciatura Plena em Dança pela Universidade Federal do Pará. Bailarina formada pela Escola de Teatro e Dança da UFPA no Curso Experimental de Formação para Bailarinosmétodo Vaganova. Técnica em Intérprete da Cena/Dança-UFPA. Bailarina em formaçãométodo Royal Academy Of Dance. É professora de Ballet Clássico atuante desde 2007.

\section{Hellen Katiuscia de Sá Conceição}

Formada em Jornalismo pela Universidade Federal do Pará, é atriz profissional, fotógrafa amadora, artista plástica e também escritora. Concluinte da Especialização em EJA ARTES - AMAZÔNIA UFPA e mestranda em Artes pela Universidade Federal do Pará 2014-2016. Dedica-se também à produção de $\mathrm{HQ}$ e animações para o audiovisual, sendo diretora, produtora e roteirista em seu grupo Studio Igara. Também atua como arte-educadora.

\section{Jaqueline Cristina Souza da Silva}

Artista visual e cênica, pesquisadora e educadora. Possui graduação em Educação Artística com habilitação em Artes Plásticas pela Universidade Federal do Pará (2005), é aluna do curso de especialização em Estudos Contemporâneos do corpo (Artes Cênicas) pelo Instituto de Ciências da Arte da UFPA, é aluna do PPGARTES Universidade Estadual de Santa Catarina UDESC pólo UFPA Mestrado Profissional em Artes (Teatro). Bolsista CAPES/UAB 2014-2016. Professora da rede estadual de ensino (SEDUC), Gestora Cultural (Fundação Cultural do Pará). É articuladora/ administradora dos blogs Auto da Barca Amazônica e Poemas e Outros Devires, ambos relacionados à reflexão de experiências em artes. Tem experiência na área de pesquisa e educação em artes, com ênfase em cultura amazônica, estéticas cotidianas, teatro de rua, performance, arte contemporânea, técnicas de produção e experimentação em artes, atuando nos seguintes temas: estudos culturais da Amazônia, Ensino das Artes Visuais e Teatro, mediação em museus. 


\section{José Ailton de Carvalho Arnauld}

Artista-pesquisador-professor. Possui graduação em Educação Artística - habilitação Artes Plásticas pela Universidade Federal do Pará (2006). Atualmente é mestrando no Programa PROFARTES na UFPA, coordenado pela Universidade do Estado de Santa Catarina (UDESC) e atua como professor efetivo na rede municipal de ensino em Belém. Está como coordenador geral da ONG Centro Artístico Cultural Belém Amazônia/ Rádio Margarida. Tem experiência na área artística, com ênfase para a produção teatral e audiovisual, atuando principalmente nos seguintes temas: arte educação, educação popular, vídeo, trabalho infantil e violência sexual.

\section{Lourdes Maria Carrera Guedes}

Possui graduação em Licenciatura Plena em Educação Artística com Habilitação em Música pela Universidade do Estado do Pará-UEPA (2000), graduação em Letras - Libras (Bacharelado) pela Universidade Federal de Santa Catarina-UFSC (2012), Especialização em Educação Especial pela Universidade Federal do Amapá-UNIFAP. Tem experiência na área de Educação, com ênfase em Educação Especial, atuando principalmente nos seguintes temas: surdez, artes, educação musical, teatro arte-educação com pessoas surdas. Arte educadora, atriz/palhaça, tradutora/intérprete de Língua Brasileira de Sinais-LIBRAS. Professora de Arte efetiva da Secretaria do Estado de EducaçãoSEDUC-PA e da Secretaria Municipal de Educação de Belém- SEMEC. Mestranda do Profissional em Artes - PROFARTES/UFPA 2014-2016. Bolsista CAPES/UAB 2014-2016.

\section{Maridete Daibes da Silva}

Possui graduação plena em Pedagogia pela Universidade do Estado do Pará (1995), Curso Técnico de Formação de Atriz pela ETDUFPA (1995), Curso de Especialização em Andamento pela UFPA/ ICA: Estudos Contemporaneos do Corpo. Desenvolve processos criativos de montagens cênicas, valorizando temas sociais e educativos no universo escolar. Professora de Teatro da Escola de Aplicação da UFPA, pedagoga, atriz, atua como educadora colaboradora em projetos sociais de bairro, integrante da Dramática Companhia, mestranda do Profissional em Artes - PROFARTES/UFPA. Bolsista CAPES/UAB 2014-2016.

\section{Priscila Romana Moraes de Melo}

Atriz/palhaça do grupo de teatro Palhaços Trovadores na cidade de Belém do Pará, artistapesquisadora, mestranda em Artes (2014) pelo Programa de Pós-Graduação em Artes pela Universidade Federal do Pará. Possui Graduação em Nutrição pela Universidade Federal do Pará UFPA (2008), Pós graduação em cursos de Especialização em Segurança Alimentar e Nutricional (2011) e em Populações Indígenas na Amazônia: Sociedade, Cultura e Meio-Ambiente (2012), ambas pela Universidade Federal do Pará. Formada pelo Curso de Iniciação Teatral, na Universidade Popular UNIPOP (2004). Desde 2007, é integrante da Associação Cultural Palhaços Trovadores. Atua em apresentações culturais ligadas ao teatro de palhaços e trabalha com Arte-Educação, ministrando oficinas corporais e de Teatro, em diálogo com a saúde, educação e assistência. Bolsista CAPES/2014-2016. 